\title{
Sanofi-Cell Research outstanding paper award of 2011
}

Cell Research (2012) 22:1511. doi:10.1038/cr.2012.153; published online 5 November 2012

We are pleased to announce the winners of the $3^{\text {rd }}$ Sanofi-Cell Research Outstanding Paper Award, which were selected from papers published in the 2011 print issues of Cell Research. The 2011 Sanofi-Cell Research Outstanding Review Article Award goes to Dr Tony Kouzarides, for his review paper entitled "Regulation of chromatin by histone modifications" [1]. The win-

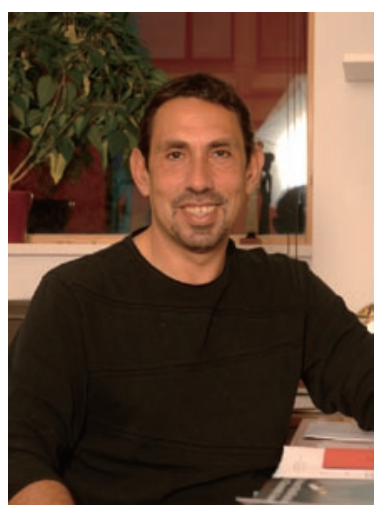

ners of the 2011 Sanofi-Cell Research Outstanding Research Article Award are Drs Bing Ren and James A Thomson, for their paper entitled "Dynamic chromatin states in human ES cells reveal potential regulatory sequences and genes involved in pluripotency" [2]; and Dr Linzhao Cheng, for his paper entitled "Efficient human iPS cell derivation by a non-integrating plasmid from blood cells with unique epigenetic and gene expression signatures" [3]. The award
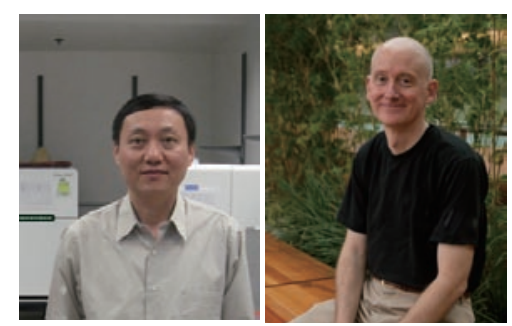

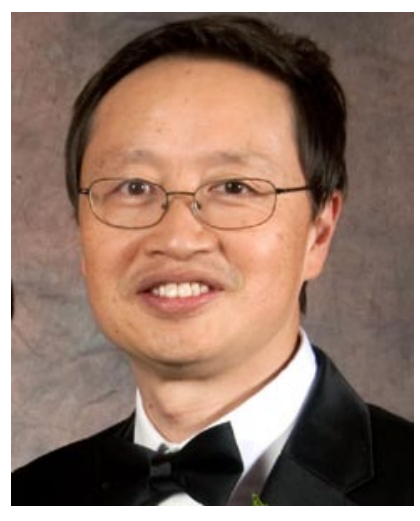

consists of a prize of $€ 3000$ for the Outstanding Review Article Award and $€ 5000$ for the Outstanding Research Article Award sponsored by Sanofi. The three award-winning papers are selected based on the voting by members of the Sanofi-Shanghai Institutes for Biological Sciences Steering Committee.

The award-winning review by $\mathrm{Dr}$ Kouzarides was published in the March issue of 2011 as part of a Special Issue on epigenetics \& chromatin, which features a collection of 9 authoritative reviews by renowned experts in the field [4]. The two award-winning research articles are both from the field of stem cell biology, an area in which Cell Research has published quite extensively in recent years [5]. Interestingly, these two papers also both feature contents related to the study of epigenetics or chromatin, as nicely reflected in their respective titles. We believe this is an indication that as Cell Research continues the rise in its academic status, we are seeing more and more papers published from the angle of inter-disciplinary studies.

We congratulate Drs Tony Kouzarides, Bing Ren, James Thomson, and Linzhao Cheng on their winning of the 2011
Sanofi-Cell Research Outstanding Paper Award, and hope that this yearly award program will continue to encourage our fellow scientists to submit their best work to Cell Research.

Dangsheng $\mathrm{Li}^{1}$

${ }^{I}$ Deputy Editor-in-Chief, Cell Research, Shanghai Institutes for Biological Sciences, Chinese Academy of Sciences, Shanghai 200031, China dsli@sibs.ac.cn

\section{References}

1 Bannister AJ, Kouzarides T. Regulation of chromatin by histone modifications. Cell Res 2011; 21:381-395.

2 Hawkins RD, Hon GC, Yang C, et al. Dynamic chromatin states in human ES cells reveal potential regulatory sequences and genes involved in pluripotency. Cell Res 2011; 21:1393-1409.

3 Chou BK, Mali P, Huang X, et al. Efficient human iPS cell derivation by a non-integrating plasmid from blood cells with unique epigenetic and gene expression signatures. Cell Res 2011; 21:518-529.

4 Zhang Y. Recent progress in the epigenetics and chromatin field. Cell Res 2011; 21:373-374.

5 Li D. A special issue on cell signaling, disease, and stem cells. Cell Res 2012; 22:1-2. 